\title{
Religion and Environment: A Case of Great East Road Baptist Women's' Christian Conference in Chong we District, Zambia
}

\author{
Inonge Milupi $\mathrm{D}^{1^{*}}$, Esther Hara-Zulu ${ }^{1}$, JudithLubasillubala-Ziwa ${ }^{2}$, Tomaida Milingo ${ }^{2}$ \\ ${ }^{I}$ The University of Zambia, School of Education, Department of Language and Social Sciences Education. P.O \\ BOX 32379, Lusaka, Zambia \\ ${ }^{2}$ The University of Zambia, School of Education, Department of Religious Studies. P.O BOX 32379, Lusaka, \\ Zambia
}

*Corresponding Author: Inonge Milupi D, the University of Zambia, School of Education, Department of Language and Social Sciences Education. P.O BOX 32379, Lusaka, Zambia

\begin{abstract}
This study contributes to the debate on religion versus environment which has been contested by many theological and academic scholars. It investigated the activities of the women from the Great East Road Baptist Churches Association (GERBCA) in Chong we who attended a Christian camp conference. The study further assessed the effects of women activities on the environment using Santmire's metaphor of ascent. Qualitative data was gathered through interviews with the women. It was found that women activities at the conference which included waste disposal which contributed to land and air pollution especially the disposal of non-biodegradable waste such as plastics. The study further found that women activity contributed to deforestation in the study area. The study therefore proposes the construction of permanent structures and to promote afforestation in the study area. Finally, it is recommended that GERBCA come up with a policy that would promote environmental sustainability among the women in the study area during religious gatherings such as camp meetings.
\end{abstract}

Key words: Environment, Women, Church, Community, Religion, Chong we, Zambia

\section{INTRODUCTION}

Discourses on environmental care have been increasing since the 1970s, when the debates were mainly based on management of resources, to the 1980s, with its concerns regarding sustainable development and the 1990s which focused on environmental injustices versus human survival amidst other emerging concerns (Conradie, 2011). Following the current environmental injustice globally, numerous calls were made upon the church to take a leading role educating the masses. In 1987, for example, the World Commission on Environment and Development, published a report headlined 'Our Common Future' which made reference to the role religion could play in addressing the damage caused to the environment (United Nations, 2010). Additionally, Tucker (2006) stated that in the 1990s, religion was recognised by scientists as a mitigating measure in solving environmental degradation as the environmental crisis required radical changes not only in public policy, but in individual behaviour. Thus, the call for commitment and assistance from religious community.

The assumption behind this call was that religion was gaining influence globally and nationally. Church and other religious organisations have assumed the role of 'communities of interpretation' in the public arena on matters initially considered secular. Religious groups that interact with the environment through camp conferences are challenged to consider the need for environmental care, such as good waste disposal practices and reforestation as an immediate local need. Church groups have the responsibility to provide direction in forming values that stress individual and joint responsibility in caring for the environment and nurturing it. Church groups also have the responsibility to provide leadership, infrastructure and networks meant to protect the environment. This could be done through applying Biblical teachings (Daneel 2006).

Contrary to the above assumption scholars who write on eco-theology have indicated that the church through its teachings perpetuate environmental misuse by the general membership. For example, 
White (1967), the American historian, argued that church goers were not only reluctant to respond to environmental degradation but also in many contexts were not environmental activists. Additionally, Kubler-Ross (1973) asserted that the church through its teachings which often took a form of spiritualizing dualisms where heaven was regarded as more important than earth, the soul as more important than the body, spirit as more important than matter, enhanced environmental degradation. Kubler-Ross further asserted that such dualisms led to an escapist denial of the need for Christian earth-keeping because many wondered: If Jesus is coming again soon, and if the world is going to be destroyed in any case, why would there be any need to care for the earth now? Santmire (1985) calls this Christian theology as 'metaphor of ascent' and that it creates a gap between human beings and the rest of creation, with the former being placed higher than the latter. This dualistic view may cause a society informed by Christianity to regard the non-human world as nothing more than a mere resource at their disposal, as a mere means for meeting human needs (Ruether, 1984). Consequently, the environment is abusively overused causing environmental degradation. This is in agreement with Pope Francis's view that human beings have contributed to global warming (Capaldi 2015). Scholars of world religion and environmental behaviour view also observed that Religious individuals and groups sometimes protect biodiversity and ecosystem resilience but more often do not (Taylor B (2019).When they do, Taylor 2019 further noted that it is often through processes in which religious beliefs and practices co-evolve in ways that are ecologically and socially adaptive.Some scholars suggested that religion can evoke ethical behaviour in believers and consequently transform attitudes towards natural preservation (Aung 2017).

The United Nations International Strategy for Disaster Reduction defines environmental degradation as the reduction of the capacity of the environment to meet social and ecological objectives, and needs (United Nations, 2004). Environmental degradation occurs when the physical environment and its resources are misused or used in a wasteful manner beyond its ideal state. In other words, it is the deterioration of the environment through deforestation, air pollution, and depletion of resources such as water, soil and extinction of wildlife. Thus, environmental degradation involves the destruction of the natural habitats and depletion of natural resources.The causes of environmental degradation include overpopulation, air and water pollution, deforestation, global warming and overconsumption. According to Tyagi and Paudel (2014), prevalent consequences of such actions include increased poverty, overcrowding, famine, weather extremes, species loss, acute and chronic medical illnesses, war and human rights abuses, and an increasingly unstable global situation that portends Malthusian chaos and disaster. Mante (2004) added that environmental degradation was also caused through secular and religious activities. For Christians, this is rather shocking since humans are given environmental stewardship to take care of the earth. Given this understanding one may ask, "Has the church lost its understanding of the initially God given responsibility?" This question was answered in this study by the researchers interacting with female members of the Great East Road Baptist Churches Association (GERBCA).

\subsection{The Metaphors of Ascent}

The study was guided by the Metaphor of Ascent advanced by Santmire (1985). His writings concentrated mainly on the discipline of eco-theology and environmental ethics. Santmire presents the ambiguity of Christianity which emerges when God is shown as implicitly having a special interest in human beings. This implicitly authorizes an apparent anthropomorphic and anthropocentric approach towards nature, that humanity has the right from God to subdue it. Nevertheless, God is portrayed as having concern for the whole of creation and the creation also has intrinsic value to respond to God. Santmire (1985) calls this the metaphor of ascent.

The metaphor of ascent is inherently anti ecological. The goal in this metaphor is to rise above the earthly world toward the supernatural realm of pure spirit. Santmire (1985) also argues that when the metaphor of ascent is continuously manifested in Christian theology, it forms the spiritual motif. The metaphor carries with it many anti-ecological views, an escapist reality and dualism. This metaphoric sense of ascent separates human beings from the rest of creation, with the former being placed higher. This dualism view makes it possible for Christians and the society informed by Christianity to regard the non-human world as nothing more than a mere resource at their disposal (Ruether, 1984). The metaphor of ascent was used to identify the general limitations and strengths of Christianity towards ecological thought and application amongst the GERBCA women who took part in the conference. 
When positioned afar, religion and environment may be perceived as two schools of thought at odds with less or nothing to do with each other. In real sense, religion and environment are largely intertwined. This is evident in scholarly works done by theologians and non-theologians from all parts of the globe on the effects of Christianity on the environment (Daneel, 2006, Ruether 2006). Scholars such as Watts (1958), White (1967), Bateson (1972), and Toynbee (1972) are among the pioneers who researched on the ecological dangers of Christianity on the environment in the late 1960's. They all warned that the Christian worldview was ecologically destructive. Though their ideas have been challenged over time, their works have been the genesis of studies on ecology versus theology and other scholarly works related to religion and environment.

Osbom (1993) gave a compelling reason why the environment should be reserved and taken care of by God's worshipers. According to Osborn, features like trees, mountains and rivers were means through which God speaks to his people. He explained that through creation people could observe God's invisible qualities, his eternal power and divine nature. So humans have no excuse, whatsoever, for not knowing God. Osbom further asserted that through nature, humans could learn about God's intelligence, power, love and care; hence, the need for humans to value nature.

Conradie and Field (2000) argue that the vision of sustainable development cannot exist without caring for the environment. This vision is a vision of the Kingdom of God since the characteristics of sustainable development are: ecological sustainability, provision of sufficient sustenance for all, a renewed relationship with creation and provision of human spiritual growth (Conradie and Field, 2000). Conradie and Field's work was used in this study because it provided the solutions to environmental degradation. By adhering to the solutions, women who belong to the GERBCA and other religious groups may have an opportunity to participate in God's agenda of having a beautiful kingdom in place.

Additionally, Gitau (2000) challenges the church to seriously think about the role it plays in correcting the errors made in the past of forgetting to care for the environment. According to Gitau, the future of humankind depends on the positive management of the natural resources with which the earth is gifted. Added to this is Murekezi's (2004) views that Christian teachings, and insights from the African heritage are seen as reliable sources that Christians can use on in tackling the environmental crisis. Furthermore, Vandyke (1996) brings the attention of Christians to the principle which states that Christians ought to love what God loves and hate what God hates. Based on this principle, Vandyke urges Christians to understand what God's creation means to them as individuals and members of different communities. This may not only help the Christians to discover the need to sustain the environment but also to experience both the joy and service involved in God's plan for a redeemed creation. Murekezi (2004) supports this argument which he refers to as a fundamental principle meant to motivate Christians to care for and maintain a good relationship with the rest of creation. Murekezi adds that God cares for his creation and wants harmony to prevail among creation. This ecological theology was used in this study to assess how the GERBCA women conference demonstrated their love for God by caring for the environment.

Don (2002) disapproves the very widely used notion 'man as master over nature'. He supports his opinion that God is the creator of everything. God is the owner of heaven and earth and everything in them. Furthermore, in strengthening the interrelationship between God and creation, Berry (2000:23) stated that:

The Bible is unequivocal in stating that the world belongs to God and has delegated its care and protection to us. We have no license to plunder creation, but we have a charge to care for the cosmos that God loves. We are not asked to look after a world that is only a "thing"; we are required to be God's agents in managing a world that he created, redeemed and sustains.

The above eco-theological views were used in the current study as timely reminders to Christians who regarded nature as mere means to satisfy their desires to have their perceptions readjusted and guard God's environment with care. Additionally, Mukaria (2017) blames Christian teachings as the main contributing factor to deforestation and air pollution. During his study, some of his participants stated that Christianity fostered teachings which devalued and marginalized nature. He further observes that such teachings were related to viewing human beings as the centre of creation or that humans were 
superior to nature. In view of this, Mukaria concludes that nature loses its sacred intrinsic value and is viewed in terms of its material value.Field (2001), suggests that if trees are cut for fuel or other means, the people should put down measures to plant other trees and maintain the remaining ones that sustain the soil from erosion. To work against this evangelical motivation would be against God's revelation to his people and deprive future generations from accessing the wonderful work because trees and other species would have been exterminated. Field's study was reviewed as it provided precedence and motivation for us to engage with the female members of the GERBCA as we endeavoured to determine how their camp conferences affected the environment. Generally, the reviewed literature agreed that Christians had the responsibility to use natural resources according to God's desire and intended purpose of safeguarding the environment.

The main aim of the GERBCA included co-ordinating member churches and church institutions to carry out the Great Commission of the Lord Jesus Christ, promote church growth in multiplying and training disciples among member churches, create co-operation and mutual understanding among member churches and to mobilize spiritual, human, socio-economic and material resources from member churches, mobilize and co-ordinate prayer support among churches and partners, empower ministries to minister effectively to the churches and communities and to research and develop materials and resources appropriate to the needs of member churches and communities.

In this paper, we aim to find out effects of womenactivities from the Great East Road Baptist Churches Association (GERBCA) in Chong we who attended a religious camp conference on the environment. The study further proposes environmental sustainability measures among Chong we women.

\subsubsection{Description of the Study Area}

The study area was Chong we, a rural district in Lusaka province of Zambia (Figure 1). The district is situated to the east of Lusaka, astride the Great North Road. Local relief in the district varies between 300 and 1300 meters above sea level (Smart Zambia Institute, SZI 2019). The geographical coordinates for Chong we are $15^{\circ} 21^{\prime} 0^{\prime \prime}$ South and $28^{\circ} 42^{\prime} 0^{\prime \prime}$ East. The Soli people are the original inhabitants of Chong we district under the chieftainship of Nkomeshya Mukamambo II.

Chong we district has three main types of vegetation. These include dry miombo (Brachystegia) woodland, mopane (Colophospermummopane) woodland, and munga (Acacia) woodlands. The vegetation, however, has been tempered with due to settlement, charcoal production and agriculture. In Zambia, most of the rural people derive their livelihoods from charcoal production and gardening. Both charcoal production and agriculture are very common in Chong we district because of its proximity to Lusaka where the products find a ready market (Milupi 2008; Milupi et.al. 2020). Agriculture is the mainstay of the economy of the district. Agricultural activities include crop production, horticultural production and livestock production (Milupi et.al. 2020).

Chong we district has a population of 182,174 people (Central Statistical Office, 2010). Of these, 92,909 (51\%) are female while 89,265 (49\%) are male (CSO, 2010). Due to its closeness to Lusaka, Chong we is experiencing rapid population growth because more and more people are looking for residential plots in the district. The district was selected because of its close proximity to Lusaka where the researchers reside. Located only $35 \mathrm{~km}$ from Lusaka, Chong we is an easy to reach town from the city.

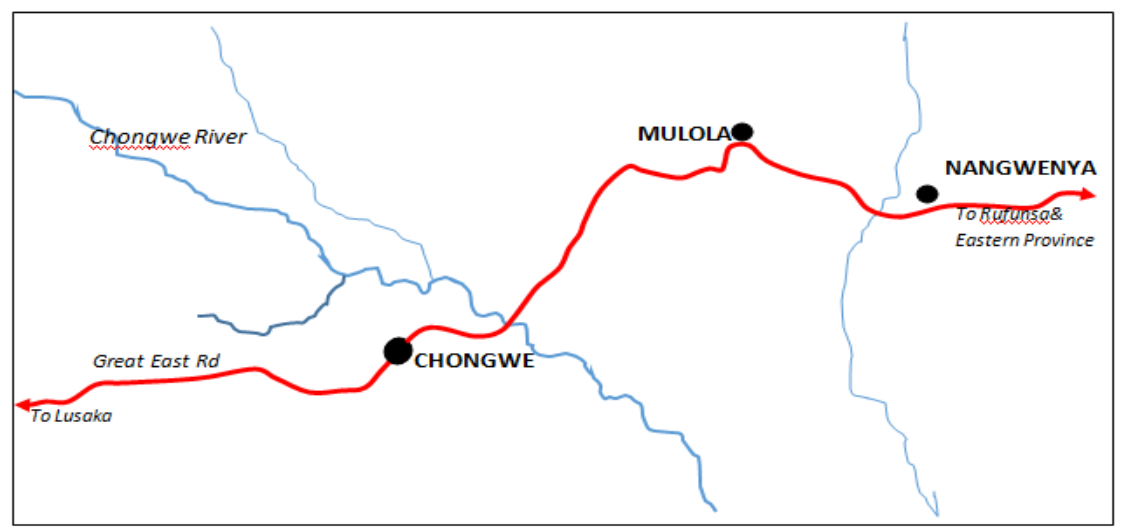

Figure1. The location of the Mulola within Chong we District 


\title{
2. Methodology
}

The study was qualitative in nature and involved four women and one of female religious leader of the GERBCA who participated in the camp conference as respondents and two female Mulola community members as respondents. Purposive sumpling technique was used to sample the five GERBCA respondents. The female religious leader was sampled first based on the fact that she was at the heam of organising the conference therefore should have the information required for in the study. The female religious leader then organised purposively the other four women to participate as respondents. The study used pseudo as follows: Hannah, Dorcas, Anna and Lydia for the four GERBCA women. The two female Mulola community members were sampled using the availability sampling which is one of the purposive sampling. Data was collected using interview and observation methods. The study also relied on document review of different literature and resources posted on the internet. With regard to analysis of data, raw data was thematically categorised and later analysed.

\section{FINDINGS}

\subsection{Activities Before the Conference}

With regard to the activities undertaken before the conference, the religious leader indicated that the activities included meetings of the executive committee consisting of the branch Chairladies who planned for the conference by discussing what the theme of the conference would be so as to know what sub topics should be discussed at the conference. The committee also sought ways of raising funds through contributions from the members and other well-wishers, and through other activities such as selling printed wrapper (chitenge) materials. The religious leader added:

\begin{abstract}
Before the conference, letters are sent to the churches concerning the date, location and what to carry to the conference. The women also make either personal or group contributions of food, money and one tin of maize each. The host church makes preparations in terms of structures such as bath rooms, places for sleeping and ensures that there is enough biofuel such as fire wood and charcoal.
\end{abstract}

Anna also indicated that since the conference was held near Mulola School, the facilities available for accommodation were four classrooms and the church. She added that a thatched barrier was built in an open area to block the wind from destroying the kitchen facility. Furthermore, Lydia added the following:

\section{The visiting women that attend the conference only bring cups and plates while the host church members provide other necessary utensils such as pots and cooking sticks. For the bathrooms, six makeshift bathrooms are built to add on to the two main bathrooms located in the school. Additionally, there are two toilets constructed at the church and four are at the school.}

According to the religious leader, the committee ensured that the facilities were enough by visiting the area where the conference would be held and comparing the available facilities against the expected number of women to attend the conference. The chair leader of the conference concluded by stating that, the Mitengo Club gave the committee information on how to keep the environment clean.

\section{Impact on the local environment as a result of the above activities}

There was some deforestation due to fibre harvesting and cutting of trees for:

i) construction of six makeshift bathrooms and a barrier for the space used as the kitchen facility,

ii) Charcoal production and fire wood.

\subsection{Activities During the Conference}

Dorcas indicated that the activities undertaken during the conference began with early morning prayers. She also indicated that lessons from the Bible on housekeeping, giving and kindness were taught. Lydia further indicated that the women designed sketches or short plays that were aimed at teaching lessons on loyalty, forgiveness, honesty and cleanliness. The sketches helped to strengthen the bond between the women and their God and families. Hannah also added that some of the 
sketches which were performed helped the women to share their personal problems which they might not have managed to share in everyday life. Furthermore, Anna indicated that through choirs the women deepened their faith.

\subsubsection{Care for the Conference Facilities During the Conference}

Participants generally indicated that to ensure cleanliness during the conference announcements were made regarding the locations of the bathrooms, toilets, dumping sites upon arriving. A duty rota was also prepared stating the names of individuals who had volunteered to do the work. Hannah also said, "We maintain cleanliness and good hygiene through sweeping the environment." Dorcas added that apart from volunteers, each church Chairlady selected five members to do daily cleaning routines every morning. Anna also indicated that any left-over food stuff was discarded into pits and that the utensils were cleaned before and after use.

\subsubsection{Waste Management During the Conference}

With regard to the management of waste materials that take a long time to decompose such as plastics and empty sacks, the church leader indicated that:

\section{Such materials are gathered and burnt to prevent them from adding dirt to the place. As for waste that easily rot such as left-over food stuff, these are discarded into pits and buried or given to people rearing pigs and chickens who may use them as feed.}

Additionally, Lydia indicated that in order to ensure sustainable use of resources such as water, electricity and firewood, the women kept the water used strictly for cooking and drinking in drums, while that for bathing was drawn directly from the taps at the school. The firewood was used to the maximum and the fire was put out when not in use to prevent any further fires. Hannah indicated that firewood was scarce so there was no room for misusing it (as shown in Figure 1). The church leader concluded, "Electricity is only used for conference services and nothing else." When she was asked how deforestation could be mitigated in the area, she suggested planting of fast growing trees.

\subsection{Activities After the Conference}

The activities that were undertaken after the conference were summarised by the religious leader as follows:

\subsubsection{The Conference Environment}

After the conference we ensure that the environment is kept clean by having the women work according to the responsibilities assigned to them. They have to sweep the surroundings, clean the utensil and dispose off generated waste in designated places. Finally, the committee holds an interactive meeting with the Mitengo club to brief them about the conference.

\subsection{Benefits of the Conference}

The researchers also sought to establish the benefits of the conference to the women participants. According to the religious leader, the conference helped women to be together as women, away from the chores and burdens of everyday life where they faced challenges related to upbringing of family members, marital and social relationships. She added that through the lessons taught, the women acquired knowledge and skills such as respect and problem solving skills. This was supported by Dorcas who indicated that:

When I am at the conference, I benefit through asking questions on

Bible related topics. This helps me to strengthen my spirituality. I

have also learnt how to pray in accordance with God's will and I

even pray for others, such as neighbours, other than my family members.

Hannah added that she learned how to be a committed Christian who was able to teach others how to be kind and generous. Additionally, Lydia indicated that the conference helped her in that she learned that spiritual growth was acquired through consistent reading of the Bible, adhering to and applying 
the teachings in her life. She added that since the conference was held at a camp, she became closer to the environment and valued it as she understood that the conference could not be held without nature. This helped her to have a close relationship with God, the creator of natural things.

With regard to the benefits of the other members of the church, one of the Mulola community members indicated that the members benefited through interacting with the women who had attended the conference. She added that some of the women were married so they shared their experiences with family members. The other Mulola community member indicated that members of the church who interacted and listened to the experiences of the women became more God fearing. She added that their families experienced better and stronger relationships with one another. She further added, "Generally, women who attend the conference seem to value the environment better as they keep the surroundings very clean."

Anna also added that even church members who did not attend the conference learnt the acquired lessons from those who attended. She further indicated that the behaviour of the women who attend the conference differed from their earlier behaviour.

The study also sought to determine the benefits of the conference to the community. In response, the religious leader indicated that the women came from different backgrounds and interacted with different people other than the Baptists. It was, therefore, inevitable that they shared what they learnt with them. Lydia further added that the women who attended the conference became beacons of good faith since they lived well in their communities. So some church community members followed their example by attending the conference too. Furthermore, Dorcas added that apart from community members changing in terms of behaviour they also learnt how to help the needy. "Thus, more women members of the church became interested in attending the conference too," concluded Dorcas.

\subsubsection{Effects of the GERBCA Women Conference on the Environment}

The environmental effects of concern were narrated by Anna that if children used other places rather than toilets, this could attract flies and result in disease outbreak. It also meant that the soil would be filthy and the air within the camp would also be polluted. She added that if left over food was not properly disposed of, the environment would be ugly to look at. Hannah added that it was of environmental concern if plastics were not properly discarded.

From the observation of the research assistant, it was established that there were grass makeshift structures that were constructed at the camp site which included one big structure meant for lodging by the women campers, bath rooms with compartments (as shown in Figure 2) and another structure meant for cooking space. These structures were made using stems or logs of trees, fibre from trees and elephant grass.

With regard to caring for the environment, the religious leader stated that there was no specific policy in place. Information on the need and how to take care of the environment was given by the Mitengo Club. "Furthermore, the Bible teaches us that we have udindo (authority) over the environment, so we need to take care of it as we use it," the religious leader added.

With reference to what should be done to prevent the cutting down of trees for the construction of makeshift structures, the religious leader suggested that the association could embark on the construction of permanent structures to be used during conferences, though this would be against the intended purpose of camping.

\section{DISCUSSION}

The study gathered sufficient information to be discussed in the context of environmental degradation, with reference to Santmire's metaphor of ascent. From the findings, we established that the GERBCA women showed concern for the environment during their activities as they disposed-of items like left over biodegradables in an environmentally friendly manner. This shows that it is not always the case that religious groups place spirituality higher than the environment. The GERBCA women used the environment to get resources, such as poles and firewood, that they needed in order for the conference to be successful. However, the women did all these activities as mere traditional acts not with the knowledge of environmental stewardship. If they wanted, they could not engage in any activity to do with environmental care and still remain answerable to no one. In other words, their actions were 
based on the desire to stay in a clean environment not necessarily as a concern for the environment. This observation is in harmony with Conradie (2011), who asserts that in their acts of environmental care, Christians do not do anything distinctly Christian. It is purely pragmatic, responding to a particular need. In the case of the GERBCA women, the need to keep the environment clean was a response to what they were taught by Mitengo Club members, not what the Bible required.

Furthermore, data gathered from the religious leader showed that the conference was organized to benefit women on various social and spiritual matters. For example, how they were to overcome social problems encountered in society as well as how they could attain a state of spiritual growth. From the first item in their agenda to the last, environmental matters did not feature though the programme could not succeed without the use of nature.

The study also established that trees that were cut for firewood and construction of temporal structures were not replaced through planting of other trees. Trees play a very important role in reducing the amounts of carbon dioxide in the atmosphere through a process called photosynthesis. Thus, when trees are cut it results in the decrease of the carbon sink, leading to an increase in carbon dioxide in the atmosphere which acts as a thick blanket causing global warming. This finding vindicates the claim by scholars (Osbom, 1993 and Field, 2001) who stated that Christians were not only selfish but also unfair to future generations and God who uses nature to communicate his invisible qualities to humankind and whose will is that people should know him through creation.

The study also established that, the GERBCA women did not do much in adhering to God's call to care for the environment. The women focused more on preaching the Gospel of salvation than environmental care. The knowledge that the women acquired on environmental care was mainly from NGOs who sensitized them at different intervals before and after the conference. This was in harmony with the findings by Mukaria (2017) whose participants held the view that the church should be silent on ecological issues as they were entirely the duty of politicians and environmentalists.

With reference to Santmire's metaphor of ascent, which emphasises that religion contributes to environmental degradation, the findings showed that in their quest to strengthen their faith, the GERBCA women caused detrimental effects to the environment related to deforestation and air pollution. However, to some extent the women did what they could to ensure that the environment was kept clean. It was also commendable that they used the same premises whenever it was the turn for Mulola Baptist Church to host the conference. The problem was that the makeshift structures that the women constructed contributed to degradation of the environment and depletion of natural resources particularly trees.

Nevertheless, the conference united women from all backgrounds and cultures. The women taught each other different skills such as assertiveness, self-awareness and cooperation, share knowledge and ideas, and ask questions to each other for the benefit of all the participants, their families, community and society at large. Most of all, the conference was a means of helping women to come together and discuss issues concerning their daily and spiritual lives which they could not discuss with their male counterparts. Finally, the conference was inevitably a coping mechanism to challenges the women might have faced.

\section{CONCLUSION}

Santmire's ascent metaphor makes reference to the way in which humans misuse the natural environment and destroy it for their spiritual development. The GERBCA women therefore fit Santimire's ascent metaphor as they focused on their spiritual growth while not minding their destructive actions of deforestation and air pollution on nature. The findings of the study showed that while the GERBCA women appreciated the importance of the environment as God's creation, tried to keep it clean through various activities knowing its importance to them, their families and community, they did not have a deliberate policy to ensure that sustenance of the environment prevailed. The GERBCA should therefore put a deliberate policy to teach women the significance of the environment and how to take care of it. There is also need for construction of permanent structures for use during conferences as well as planting of trees activities during or at the end of the conference.

\section{RECOMMENDATIONS}

The following are the study's recommendations 
- The study proposes the construction of permanent structures and to promote afforestation in the study area.

- There is need for the GERBCA to come up with a policy that would promote environmental sustainability among the women in the study area during religious gatherings such as camp meetings.

\section{ACKNOWLEDGMENT}

The authors would like to thank the GERBCA women who participated in the interviews and all the respondents from the association who played a part in the genesis and completion of this research.

\section{REFERENCES}

[1] Aung T. S (2017). The Role of Religion in Environmental Preservation: The Study of World Major Religions. Journal of Asian and African Social Science and Humanities, 3(1): 45-66

[2] Bateson, G. (1972). Steps to Ecology of Mind. Chicago: University of Chicago Press.

[3] Berry, R.J. (2000). The care of Creation: Focusing Concern and Action. Leicester: Inter-Varsity Press.

[4] Capaldi, N. (2015). A Critique of Pope Francis's Laudatosi'. Available from: https://digitalcommons .law.seattleu.edu/sulr/vol40/iss4/6/ [Accessed $12^{\text {th }}$ August 2019].

[5] Conradie, E. \& Field, D. (2000).A Rainbow Over the Land: A South Africa Guide on the Church and Environmental Justice. Sybrand Park: Western Cape Provincial Council of Churches.

[6] Conradie, E.M. (2011). Christianity and Earth keeping: In search of an Inspiring Vision. Stellenbosch: SUN Press.

[7] Daneel, L. M. (2006). 'African Initiated Churches as Vehicles of Earth - Care in Africa', in Roger S Gottlieb (ed.,), the Oxford Handbook of Religion and Ecology, Oxford University Press: Oxford.

[8] Fields, L. (2001). Friends of the Earth, Vol. 33, \#3, Fall.Retrieved May 15, 2019.

[9] Gitau, S.K. (2000). The Environmental Crisis: A Challenge for African Christianity. Nairobi: Action Publishers.

[10] Kubler-Ross, E. (1973). On death and Dying. London: Tavistock.

[11] Mante, J.O.Y. (2004). Africa: The Theological and Philosophical Roots of Our Ecological Crisis. Accra: Sonlife Press.

[12] Milupi I, (2008).Environmental education activities among Chong we rural women of Zambia arising from environmental degradation of their area. Findings from a Masters Dissertation submitted to the University of Zambia, Lusaka.

[13] Milupi I, D., MoongaS, Chileshe B and Monde P ( 2020) "Women and Natural Resource Conservation: A Study of Chong we District, Zambia" International Journal of Humanities Social Sciences and Education (IJHSSE), vol 7, no. 3, 2020, pp. 22-30. doi: http://dx.doi.org/10.20431/2349-0381.0703004.[Accessed on 4th July 2020]

[14] Mukaria, A.R. (2017), "Towards Constructive Eco-theology: The Mau Forest Complex Degradation and the Response of the Church". PhD Thesis, MF-Norwegian School of Theology.

[15] Murekezi, F.F. (2004)."Poverty, Environment and Church: A Christian Contribution to the Earth Crisisas a Key to Poverty Eradication, a Zambian Perspective". Master's Thesis, University of KwaZulu-Natal.

[16] Osbom, L. (1993). Guardians of Creation: Nature in Theology and the Christian Life. Leicester: Apollos.

[17] Ruether, R. R. (1984), Women and Redemption: A Theological History. Minneapolis: Fortress Press.

[18] Ruether R. R., (2006). 'Religious Ecofeminism: Healing the Ecological Crisis', in Gottlieb S. R., The Oxford Handbook of Religion and Ecology. Oxford University Press, Oxford.

[19] Santmire, H.P.(1985). The Travail of Nature: The Ambiguous Ecological Promise of Christian Theology. Minneapolis: Fortress Press.

[20] Taylor B (2019). Religion and environmental behaviour (part one): World religions and the fate of the Earth. The Ecological Citizen 3: 71-6.

[21] Toynbee, A. (1972). "The Religious Background of the Present Environmental Crisis", International Journal of Environmental Studies, 3:1-4, 141-146.Available from: https://www.tandfonline.com/doi/abs /10.1080/00207237208709505. [Accessed 23 ${ }^{\text {rd }}$ June 2019].

[22] Tucker E. M. (2006), 'Religion and Ecology: Survey of the Field', in Roger S Gottlieb (ed.,), the Oxford Handbook of Religion and Ecology, Oxford University Press: Oxford.

[23] Tyagi.S. \&Paudel.R. (2014). "Environmental Degradation: Causes and Consequences". European Researcher, 2014, Vol.(81), № 8-2 pp. 1491-1498 
[24] United Nations (2004), The International Strategy for Disaster Reduction. Available from: www.unisdr.org/eng/library/lib-terminology-eng\%20home.htm[Accessed 23 ${ }^{\text {rd }}$ June 2019].

[25] United Nations (2010). Our Common Future - Sustainable Development and Knowledge. Available from: https://www.sustainabledevelopment.un.org [Accessed 23 ${ }^{\text {rd }}$ June 2019].

[26] Vandyke, F.(1996).Redeeming Creation: The Biblical Basis of Environmental Stewardship. Illinois: Inter Varsity Press.

[27] Watts, A. (1958). Nature, Man, and Woman. UK: Thames \& Hudson.

[28] White, L. (2010). "The Historical Roots of our Ecological Crisis". Available from: https://www.uvm.edu/ gflomenh/ENV-NGO-PA395/articles/Lynn-White.pdf. [Accessed 15 ${ }^{\text {th }}$ May 2019].

\section{AUTHORS' BIOGRAPHY}

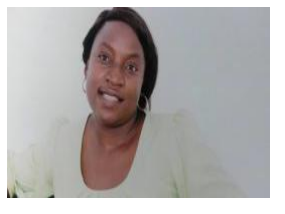

Inonge Milupi D. (PhD), is a lecturer and researcher of Environmental Education at the University of Zambia. Her research interest includes environment and society, climate change as well as Local Ecological Knowledge (LEK).

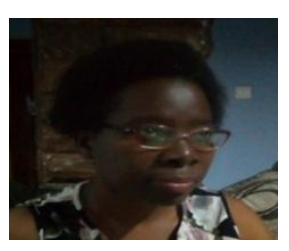

Esther Hara - Zulu, is a lecturer in the Department of Language and Social Sciences Education at the University ofZambia (UNZA) and is currently a research fellow. Her research interests are in geography education, environment, and socio-economic development as relates to gender.

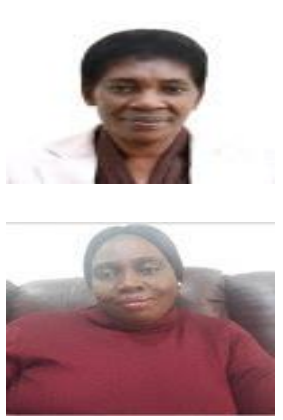

Judith L. Ilubala-Ziwa(PhD), is a lecturer and researcher of Religious Studies at the University of Zambia. Her research interests include religion, society and environment, indigenous knowledge and religion and gender.

Tomaida C. Milingo (PhD), is a lecturer and researcher of Religious Studies at the University of Zambia. Her research interests are Religion and Women, Religion and Society, Religion and Culture and Religion, Education and Gender.

Citation: Inonge Milupi D, et.al. "Religion and Environment: A Case of Great East Road Baptist Women's' Christian Conference in Chong we District, Zambia" International Journal of Humanities Social Sciences and Education (IJHSSE), vol 7, no. 7, 2020, pp. 189-198. doi: http://dx.doi.org/10.20431/2349-0381.0707021.

Copyright: (C) 2020 Authors. This is an open-access article distributed under the terms of the Creative Commons Attribution License, which permits unrestricted use, distribution, and reproduction in any medium, provided the original author and source are credited. 